\title{
Potential Supply of Midwest Cropland for Conversion to In-Field Prairie Strips
}

Zachary R. Luther ${ }^{1}$, Scott M. Swinton ${ }^{2 *}$, and Braeden Van Deynze ${ }^{3}$

${ }^{1}$ Zachary R. Luther is Ph.D. student, Department of Economics, Vanderbilt University. zachary.r.luther@vanderbilt.edu. VU Station B, Box \#351819, 2301 Vanderbilt Place, Nashville, TN 37235 .

2* Scott M. Swinton is chairperson and University Distinguished Professor, Department of Agricultural, Food, and Resource Economics, Michigan State University, swintons@msu.edu. 446 West Circle Drive, East Lansing, MI 48824-1039.

${ }^{3}$ Braeden Van Deynze is Postdoctoral Research Associate, School of Marine and Environmental Affairs, University of Washington, vandeynz@uw.edu. 3707 Brooklyn Ave NE, Seattle, WA 98105.

$\underline{\text { Key words }}$

Agricultural conservation; agricultural policy; ecosystem services; environmental supply; payment for environmental services; prairie strips.

JEL codes: Q15, Q18, Q57 


\section{Abstract}

Prairie strips planted into crop fields offer multiple environmental benefits. This study estimates the willingness of U.S. farmers to convert $5 \%$ of their largest corn-soybean field to prairie strips in exchange for payment. Using stated preference results to estimate land supply, we find that $20 \%$ of farmers are willing to adopt prairie strips at payments equivalent to average Conservation Reserve Program (CRP) rental rates, corresponding to potential conversion of 90,000 acres on $1.8 \mathrm{~m}$ acres of cropland. Farmers are likelier to adopt in smaller fields and when they perceive that prairie strips will benefit environmental quality or agricultural productivity.

Appendix materials can be accessed online at:

https://uwpress.wisc.edu/journals/pdfs/LE-98-2-Swinton-app.pdf 


\section{Potential Supply of Midwest Cropland for Conversion to In-Field Prairie Strips}

\section{Motivation}

Prairie strips planted into crop fields represent a novel conservation practice that can provide a wide array of ecosystem services. Strips planted along an elevation contour and occupying as little as $5 \%$ of farm fields have been shown to drastically reduce soil erosion and nutrient runoff, providing both a private soil conservation benefit and a public water quality benefit (Zhou, Al-Kaisi, and Helmers 2009; Helmers et al. 2012; Hernandez-Santana et al. 2013). The practice can also provide habitat for beneficial species such as birds, pollinators, and the natural enemies of agricultural pests (Schulte et al. 2016; Schulte et al. 2017). Prairie strips are functionally similar to perennial grass crops and in-field buffer strips, which have been shown to improve arthropod abundance and biodiversity (Haaland, Naisbit, and Bersier 2011; Gill, Cox, and O’Neal 2014; Werling et al. 2014; Lane et al. 2020), as well as carbon sequestration (Bouchard et al. 2013).

The environmental benefits that prairie strips offer prompt inquiry into their potential appeal as a conservation practice. In spite of the favorable academic reviews of their performance, by 2017 prairie strips had been adopted by fewer than 100 American farmers (Love 2017). Following the 2018 Farm Bill (US Congress 2018), the practice became eligible for federal support in 2019 under the Conservation Reserve Program (CRP) Clean Lakes, Estuaries and Rivers (CLEAR) initiative. As of February 2021, nearly 10,000 acres of prairie strips had been installed under the CRP-CLEAR contracts, with particularly high adoption in Illinois and Iowa (USDA Farm Service Agency 2021). While these numbers indicate growing interest in prairie strips, there exists scant economic research on the drivers and potential scale of prairie strip adoption. 
Farmer adoption of prairie strips will depend not only on the private and public benefits realized, but also on how farmers perceive those benefits and what costs farmers must incur to plant and maintain prairie strips. Although Tyndall et al. (2013) produced a fine cost budgeting study for a representative Iowa farm, there exists no study to date of the potential supply of prairie strips that captures the heterogeneity of farmer preferences, farm resources, or other potential drivers of conservation practice adoption behavior. In this paper, we use a stated preference approach to examine both monetary and non-monetary determinants of prospective prairie strip adoption in the Eastern Corn Belt of the United States. By capturing farm and farmer heterogeneity, we are able to predict the potential supply of cropland for prairie strip adoption at increasing incentive payment levels. The supply function approach underpinning our research builds upon the costs of prairie strip adoption, adjusted for farmer preferences.

In order to adopt prairie strips, farmers incur costs, both direct and indirect. The direct costs follow the sequence of tasks to install the strips. A farmer adopting prairie strips must first prepare the planting site through intensive tillage and removal of vegetation (Schulte Moore, Youngquist, and Helmers 2017). In doing so, the farmer incurs costs for labor and equipment, and sometimes financing costs to boot. Second, the farmer must plant the prairie strips, incurring costs for native seed and seeding by hand or mechanically (Schulte Moore, Youngquist, and Helmers 2017). Third, the farmer must maintain the prairie strips through grazing, mowing, or controlled burning (Schulte Moore, Youngquist, and Helmers 2017). During this maintenance phase, material and labor costs continue, although annual expenditures are lower than during the site preparation and establishment phases (Tyndall et al. 2013).

Beyond direct costs, farmers incur indirect, opportunity costs due to shifting prairie strip land out of crop production. Tyndall et al. (2013) found that at least $50 \%$ of the total costs that farmers incurred 
from planting prairie strips stemmed from lost crop revenue. Such opportunity costs are hard to measure because they vary with crop yield and price.

Apart from direct and indirect monetary costs, farmer decisions on whether to adopt prairie strips may also depend on how they perceive the ecosystem services and disservices that the strips provide to adjacent cropland and to the broader environment. Perennial buffer strips of prairie species have been shown to increase plant biodiversity within agricultural catchments without increasing weed populations on adjacent cropland (Hirsh et al. 2013). While vegetated strips have the potential to compete with adjacent row crops (Guto et al. 2011), prairie strips have been shown not to decrease crop yields beyond the area that is taken out of crop production (Schulte et al. 2017). However, the impacts of some ecosystem services from prairie strips on local agricultural productivity are still unclear. For example, while prairie strips can increase the abundance and diversity of pest predators on adjacent cropland, these improved populations do not necessarily lead to increased rates of local pest predation on that cropland (Cox et al. 2014).

If incorporating prairie strips into crop fields offers positive net benefits to society but not to farmers, farmers may need incentives via a payment-for-ecosystem-services (PES) program (Swinton et al. 2015; Ma et al. 2012). Incentives to enhance financial appeal and to redress resource constraints are among the economic factors that affect the adoption of agricultural conservation practices in the United States (Luther, Swinton, and Van Deynze 2020; Prokopy et al. 2019). By using a survey-based experiment to elicit willingness to participate in a hypothetical conservation program in exchange for a PES payment (Mooney, Barham, and Lian 2015; Skevas et al. 2016), we are able to trace out the potential supply of prairie strip land. Such an experiment can also elucidate non-pecuniary factors that affect farmer decisions, ranging from personal preferences to farm resource capacity. 
This paper aims to make three major contributions to the existing economic literature. First, we go beyond representative budgeting of direct and indirect monetary costs (Tyndall et al. 2013) to investigate the willingness of real farmers to incorporate prairie strips into their own fields.

Heterogeneity in farm location and resource capacities has been shown to affect the costs and likelihood of adoption of other conservation practices (Prokopy et al. 2019), so we expect to see a range of willingness to plant prairie strips. Second, we explore the expected benefits that farmers perceive from adopting prairie strips. Past research shows that farmers are likelier to adopt conservation practices if they exhibit high environmental awareness (Pannell et al. 2006; Luther, Swinton, and Van Deynze 2020) or if they perceive that a practice will yield greater private benefits (Chouinard et al. 2008). Third, we explore how farm and farmer heterogeneity influence not only the determinants of prairie strip adoption, but also the potential aggregate supply of prairie strip land.

Our study has three objectives: 1) to determine the adoptability of prairie strips by farmers in the Eastern Corn Belt, 2) to measure the nonmonetary factors that affect Eastern Corn Belt farmer decisions about prairie strip adoption, and 3) to predict the potential supply of land in the Eastern Corn Belt that could be devoted to this unique practice that blends elements of working lands conservation practices with land set aside.

We address these research objectives using a cross-sectional data set from a 2018 mail survey of farmers in Illinois, Indiana, Michigan, and Ohio. These Eastern Corn Belt states represented 30.4\% of corn and soybean land in the entire U.S. Corn Belt in 2017 (USDA National Agricultural Statistics Service 2021). The Corn Belt acts as a major contributor to agricultural output, as well as to agricultural water pollution, notably algal blooms in Lake Erie and hypoxia in the Gulf of Mexico (Daloğlu et al. 2014). Using results from a stated preference experiment that offers compensation for converting five percent of a crop field into prairie strips, we predict a supply function for cropland convertible to prairie 
strips. We find that $20 \%$ of farmers are willing to adopt prairie strips in exchange for payments equivalent to average Conservation Reserve Program (CRP) rental rates in their states. Farmers are likelier to adopt on smaller fields, when they already participate in conservation programs, and if they perceive that prairie strips will have favorable impacts on environmental quality and/or agricultural productivity. We project that farmers in the Eastern Corn Belt would be willing to plant about 90,000 cropland acres of prairie strips inside their largest fields if paid \$159 per acre, the average current CRP payment in the region.

The paper proceeds with a conceptual model of the farmer decision to plant prairie strips. We then describe the data collection process and econometric methods, present our empirical findings, including results from a model of the binary choice of adopting prairie strips and the implied supply in response to varying PES payments. We close with a discussion of what these findings mean for policy and how they fit into the growing literature on prairie strips.

\section{Conceptual Model}

As a conceptual framework, we build on Dupraz et al.'s (2003) environmental supply model to describe a representative farmer's decision on whether to enroll one crop field on their farm in a conservation program, accounting for private benefits and costs as well as their response to government payments that compensate public benefits.

We assume that farmers choose the proportion of one field to convert to prairie strips $(\alpha \in[0,1))$ in order to maximize their utility. The utility function in Equation (1) is separable in consumption of market goods $(C)$ and non-market environmental amenities $(E)$. We further assume that $E$ encompasses both privately consumed environmental amenities and satisfaction from provision of public 
environmental amenities to others. We posit that environmental amenities are non-decreasing in $\alpha$, so $E^{\prime}(\alpha) \geq 0$.

$$
\begin{gathered}
\max _{\alpha} U[C, E(\alpha) \mid F] \\
\text { s.t. } \quad C \leq \pi+N F I \\
\pi=A\left\{(1-\alpha)\left[p_{y} Y(X, \alpha)-p_{x} X\right]+(\alpha)\left[r-p_{x c} X_{c}\right]\right\}-F C
\end{gathered}
$$

Heterogeneous characteristics of the farm and farmer $(F)$ have been shown to impact farmer behavior regarding the adoption of best management practices (Pannell et al. 2006; Prokopy et al. 2008; Baumgart-Getz, Prokopy, and Floress 2012). Consequently, we condition a farmer's utility on an array of idiosyncratic traits that include farm resource capacities, previous contact with the conservation practice, farmer age, and education (Prokopy et al. 2019).

Farmers face a budget constraint, Equation (2), such that their cost of consumption cannot exceed their revenues from non-field income $(N F I)$ plus profit from their field's output $(\pi)$. Field-level profit (Equation 3) depends on the revenue from selling agricultural goods produced from their field $(Y)$ at a price $\left(p_{y}\right)$. Field output $(Y)$ is a function of field inputs $(X)$, such as water, crop seed, and pesticides, as well as potential effects from nearby prairie strip area $(\alpha)$. Field-level variable costs come from crop production (inputs $(X)$ purchased at a prices $\left(p_{x}\right)$ ). For adopting prairie strips, the farmer may receive a PES in the form of an annualized per acre rental rate $(r)$ for setting aside the proportion $(\alpha)$ of total field area $(A)$ for conservation use, while incurring variable costs for the inputs used in managing this conservation land $\left(X_{c}\right)$ at prices $\left(p_{x c}\right)$. We formally define the farmer's profit function $(\pi)$ in Equation (3) as the sum of crop revenue net of variable costs from output $\left(p_{y} Y(X)-p_{x} X\right)$ for the proportion of total cropland $(A)$ that is in production $(1-\alpha)$, and the net revenue from managing conservation land $\left(r-p_{x c} X_{c}\right)$ for the proportion of total field cropland $(A)$ that is set aside for conservation use $(\alpha)$, minus 
fixed farming costs $(F C)$. We assume that utility increases in $C$ and $E$ at a decreasing rate: $U^{\prime}(C)>0$, $U^{\prime}(E)>0, U^{\prime \prime}(C)<0$, and $U^{\prime \prime}(E)<0$.

In order to derive a field-scale, prairie strip area supply function, we take the first order conditions to solve for $\alpha^{*}$, the utility-maximizing allocation of land that satisfies the following condition:

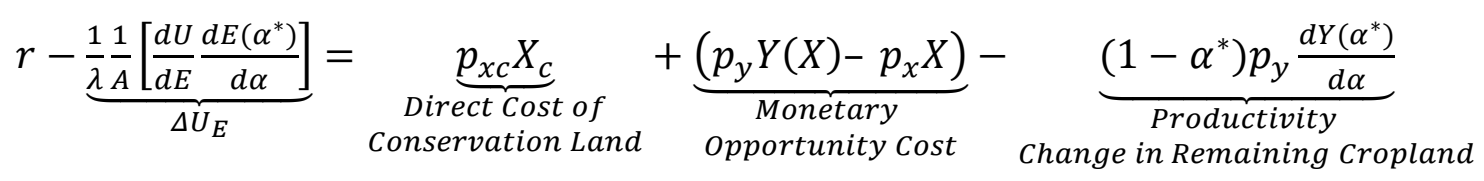

At this optimal proportion of a field allocated to prairie strips, $\alpha^{*}$, the payment for environmental services $(r)$ minus the money metric value of the farmer's marginal utility of environmental amenities, $E$, with respect to changes in the proportion of land set aside, $\alpha$, just equals the sum of the direct cost of conservation inputs and the monetary opportunity cost of lost net revenue from cropland shifted to conservation, minus the monetary value of any (positive) productivity change on the remaining cropland in the field.

The result in Equation (4) establishes expectations to underpin hypothesis tests for the driving variables in a reduced form, empirical model of field-level supply of land in prairie strips. Specifically, the land area supply function implied by Equation (4) sets four expectations for coefficient estimates from the empirical analysis of factors determining the choice prairie strip area. First, the area in prairie strips $\left(\alpha^{*}\right)$ should be increasing in the per acre rental rate $(r)$. Second, $\alpha^{*}$ should also be increasing in the perceived environmental benefits from prairie strips, which depend upon the farmer's environmental attitudes and prior participation in conservation programs. Farmers who have positive perceptions that prairie strips will increase environmental quality $(E)$ or agricultural productivity $(Y)$ and farmers who already participate in conservation programs should have a higher value of $\alpha^{*}$. Third, $\alpha^{*}$ should be 
decreasing in field area (A). Fourth, $\alpha^{*}$ should also be decreasing in direct costs $\left(p_{x c} X_{c}\right)$ and opportunity costs $\left(p_{y} Y(X)-p_{x} X\right)$ of land shifted into prairie strips.

\section{Data and Design}

\section{Survey Sample}

To measure how amenable farmers are to planting prairie strips inside crop fields, we use the 2018 Crop Management and Stewardship Practices survey, a mail survey of U.S. Eastern Corn Belt corn and soybean farmers developed at Michigan State University and co-sponsored by Purdue University and the Ohio State University. The sampling frame included farmers who planted more than 100 acres of cropland in corn or soybean in 2017 and who resided in a county with at least $15 \%$ of total land devoted to agriculture in Illinois, Indiana, Michigan, or Ohio. Farmers with 500 acres or more were purposively oversampled in order to capture a wide range of farm sizes, given that the median acre of corn and soybean harvested on U.S. farms in 2017 came from farms of 685-700 acres (MacDonald, 2020). Of 3,353 addresses contacted, the survey received 981 responses, for a $29.3 \%$ response rate. Of these responses, 487 were suitable for our analyses after accounting for item non-response. ${ }^{1}$

\section{Survey Format}

The survey employed a stated preference experiment (Phaneuf and Requate, 2016) designed to measure the willingness of Eastern Corn Belt farmers to integrate prairie strips into their corn or soybean fields in exchange for a payment. The experimental text asked respondents if they would enroll in a hypothetical contract in which prairie strips would occupy $5 \%$ of the respondent's largest field for a period of ten years in exchange for a pre-determined, annual, per-acre, payment offer. 
The stated preference portion of the survey instrument (Figure A1 in Supplemental Materials Appendix) began with a description of prairie strips and the ecosystem services that they provide. After this introduction and a question about previous contact with the practice, respondents reviewed a hypothetical ten-year prairie strip contract. By accepting the contract, respondents would be agreeing to plant and manage prairie strips that would occupy 5\% of their largest corn-soybean field in exchange for a fixed annual per acre payment for ten years. Respondents responded to a set of Likert-scaled statements about the expected effects of planting prairie strips on environmental quality and agricultural productivity in their largest field. Finally, farmers responded to a single-bounded, dichotomous choice prompt asking if they would or would not enroll in the contract for a pre-determined payment $(\$ \mathrm{XX})$ : "Would you enroll your field in the prairie strip program at \$XX per acre per year?"

\section{Bid Selection}

To properly capture stated preferences in contingent valuation experiments, payment treatments must be chosen with care (Duffield and Patterson 1991). In our study, contract payment rates were anchored around rental payment rates from the Conservation Reserve Program (CRP). This anchoring was motivated by pre-tests with farmers, who often treated the CRP as their frame of reference. So grounding the range of PES rates in state-average CRP payments not only fit the worldview of representative respondents, but also provided a framework that is readily compared to the existing CRP.

All survey questionnaires were identical in every respect but one - the payment offer in the contingent valuation section. Twenty different payment treatments anchored around state-average CRP payments were randomly assigned to respondents (Table A2 in Supplemental Materials Appendix). For each of the four states, contract payment rates were set at $50 \%, 100 \%, 200 \%$, and $300 \%$ of the state average CRP rate for 2017 (rounded to the nearest dollar) for a total of sixteen treatments. One fifth of 
the surveys for Illinois, Indiana, and Ohio were randomly assigned to one of four additional treatments. These treatments consisted of $50 \%, 100 \%, 200 \%$, and $300 \%$ of a $\$ 175$ per acre treatment, rounded to the nearest dollar (Table 1).

\section{Empirical Methods}

Due to the accept-reject format of the stated preference experiment, the responses do not directly reveal respondents' optimal prairie strip proportion, $\alpha^{*}$, from the conceptual model. Instead, responses indicate only whether the latent variable $\alpha^{*}$ was at least five percent at a given payment level, $r$. Consequently, we estimate a binary dependent variable model where the dependent variable is the indicator,

$$
\tilde{\alpha}=\left\{\begin{array}{ll}
1 & \text { if } \alpha^{*} \geq .05 \\
0 & \text { otherwise }
\end{array}\right\}
$$

To estimate the impacts of monetary and non-monetary drivers on prairie strip adoption in the Eastern Corn Belt, we regress the binary adoption variable on a vector of explanatory variables motivated by the conceptual model. We estimate logit and probit models 1) to predict the proportion of farmers who would enroll in the prairie strip contract in response to varying incentive payment offers, and 2) to evaluate the importance of the factors driving the adoption decision. In a subsequent step, we extrapolate these results to predict the corn and soybean acreage in the Eastern Corn Belt that would be planted in prairie strips under different payment scenarios.

The explanatory variables from the conceptual model included the payment offer, the opportunity cost of foregone yield (measured via area of land contracted and perceived yield gains), direct costs (measured as perceived farm management and pest management costs), environmental disservices (measured as perceived weed and pest pressure), and environmental benefits (measured as 
perceived soil retention and prior participation in conservation programs). We developed the farmer perception variables in two steps. The questionnaire included Likert-scaled statements regarding farmer expectations of the costs and benefits from planting prairie strips. In order to reduce the number of similar variables and avoid potential collinearity, we conducted confirmatory factor analysis (Thompson 2004) to generate six factors that measure farmers' latent perceptions of the environmental and agricultural productivity impacts of prairie strips. The standardized factor loadings (scaled to one unitary loading per factor) appear in Table $2 .^{2}$

The estimated factor loadings for each mapped relationship are positive. We find that the "Perceived Soil Retention", "Perceived Biodiversity Benefit", "Perceived Yields", and "Perceived Farm Management Costs" factors exhibit loadings of particularly high magnitude, with each factor loading for each of the four factors being greater than or equal to unity. The factor loadings for the latent factors "Perceived Weed and Pest Pressure" and "Perceived Pest Management Costs" are smaller in magnitude yet still positive, suggesting a slightly weaker relationship between the observed variables that measure farmers' expectations of the impacts of prairie strips and the latent variables that measure farmers' perceptions.

Table 3 shows descriptive statistics of the empirical variables used in our analyses, along with their connection to the conceptual model and a set of testable hypotheses.

The survey intentionally over-sampled large-scale farmers (i.e., farmers with at least 500 acres of cropland) in order to capture both 1) a wide range of farm sizes to introduce sample variability in resource capacities, and 2) the adoption behavior of farmers who manage large swaths of land. Given that large-scale farmers manage a majority of U.S. cropland (MacDonald 2020), the outcomes of these farmers' management decisions have a disproportionate effect on the land. Consequently, unweighted empirical analyses capture the contract enrollment and land supply behavior of farmers who manage 
most land in the Eastern Corn Belt, whereas analyses that include survey weights to account for the survey's over-sampling to capture the enrollment behavior of a typical (but smaller scale) farmer (Solon, Haider, and Wooldridge 2015). We present both the unweighted and survey-weighted approaches in order to understand any differences in prairie strip adoption across the landscape (unweighted) versus by a representative member of the Eastern Corn Belt farmer population (weighted).

We constructed ex-post probability weights for the survey-weighted analyses based on the stratified sampling design. ${ }^{3}$ For each of the four states in the study, we sampled two size strata, one for farms with owned and rented-in cropland of 100 to 500 acres, and the other for farms of at least 500 acres of cropland. To calculate weights for each state by size stratum, we used data on the population of farms below and above 500 acres in each state from the NASS 2012 Census of Agriculture:

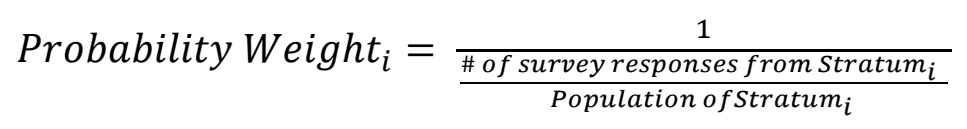

For interested readers, the Supplemental Materials Appendix contains detailed information on bid acceptances, including means and standard deviations of explanatory variables for each of the four CRP-proportional bid levels (Tables A6-A9) and bid acceptance rates by state at each level (Tables A10-A14).

We conducted choice-of-model tests to compare alternative specifications of empirical variables that conform with the conceptual model. The specifications include 1) Bid level variable only, 2) Baseline variables minus CRP/EQIP/CSP dummy, 3) Baseline variables presented here, 4) Baseline variables plus farm yield as a proportion of county average yield (yield proportion), 5) The variables in (4) plus total farmland, rented land, labor supply, livestock presence \& time horizon, and 6) The variables in (4) with total farmland and rented land replaced by a variable for the proportion of owned cropland in all cropland operated. We estimated both logit and probit procedures on both unweighted 
and survey weighted data. Due to item non-response on certain continuous variables, tests were adjusted by restricting the sample to the smallest subsample with usable values for all variables across all estimations.

Based on likelihood ratio (LLR) tests for the unweighted models and Wald tests for the weighted ones, supplemented by the Akaike Information Criterion (AIC) for each, we find that the baseline specification reported here is preferred, in that we reject the hypothesis that the model was simply the bid level variables, but we fail to reject the hypothesis that the baseline specification was improved by additional variables in nearly all instances. The only variable that fails to be significant under certain specifications is the conservation program participation variable, which we retain for the sake of theoretical consistency. Results for logit and probit estimation approaches were nearly identical in pvalues of coefficient estimates. As neither approach was preferred statistically, we report logit results. Choice of model tests appear in the Supplemental Materials Appendix, Tables A15-A19.

\section{Findings}

\section{Logit Results}

Logit results for the factors affecting farmer willingness to plant prairie strips appear in Table $4 .^{4}$ In both the unweighted and survey-weighted estimates, we find that the probability of farmer enrollment in the prairie strip contract increases with payment offer, as expected. Small-scale farmers are more responsive to changes in payments than large-scale farmers, as revealed by the larger coefficient magnitude for payment offer in the survey-weighted analysis.

Farmers who are required to allocate less cropland toward prairie strips per the contract's fivepercent conversion criterion are more likely to enroll (i.e., farmers whose largest field is relatively smaller). Again, small-scale farmers are slightly more responsive to changes in land requirements than 
large-scale farmers are, as evidenced by the larger coefficient magnitude in the survey-weighted analysis.

Farmer perceptions of how prairie strips affect their fields' environmental quality and agricultural productivity are significant drivers in their decisions to enroll in the contract. As expected, farmers are likelier to enroll in a prairie strip contract if they perceive that prairie strips will 1) increase crop yields on their fields or 2) increase soil retention on their fields. However, large-scale farmers appear to be more responsive to changes in perceived yield gains and less responsive to changes in perceived soil retention (based on comparing the unweighted and survey-weighted results). Surprisingly, there was no effect on prairie strip enrollment due to farmers perceiving that prairie strips will increase a) weed and pest management costs or b) biodiversity. However, large-scale farmers are likelier to enroll if they perceive that prairie strips will decrease farm management costs on their fields. Likewise, largescale farmers are more likely to enroll if they already participate in one of the three leading agricultural conservation programs (CRP, EQIP, or CSP). For the demographic variables farmer age, education, and previous contact with prairie strips, we find no evidence of an impact on enrollment. Neither do we find evidence that the level of non-farm employment in the farmer's household affects contract enrollment.

Using the predicted probabilities generated over the range of payment offer levels, we graph the relationship between the expected probability of prairie strip contract enrollment by payment level, holding all other covariates at their sample means (Figure 1). The predicted probability of enrollment increases roughly linearly as payment offer increases, with a predicted probability of enrollment of 0.20 at the $\$ 159$ payment level (the mean of the four state-average CRP treatments at the $100 \%$ rate). At this payment level, the probability of enrollment is the same for both unweighted and weighted analyses, though probability of enrollment grows faster for the weighted (smaller farm) analysis at higher payment offers. For comparison, the predicted probability of enrollment at a payment level of $\$ 318$ (the mean of 
the four state-average $200 \%$ CRP rate treatments) rises to 0.40 in the unweighted and 0.45 in the weighted analyses.

Breaking this relationship down by state and focusing on the unweighted predictions (with weighted ones in parentheses), we estimate that $21.9 \%(21.2 \%)$ of Illinois farmers, $21.1 \%(19.4 \%)$ of Indiana farmers, $17.9 \%$ (24.4\%) of Michigan farmers, and 20.9\% (22.3\%) of Ohio farmers would enroll in the contract with payments equivalent to the CRP state-specific average.

Although the experimental treatments offered to farmers all involved payments, we can cautiously extrapolate our results to provide a loose estimate of the percentage of farmers who might enroll in a prairie strip contract voluntarily. We find that in the absence of a payment incentive, farmers have a predicted probability of contract enrollment of 0.09 ( 0.07 using the survey-weighted approach).

\section{Estimated Supply Curve}

We can extrapolate from the results of our binary dependent variable model to estimate the supply of corn and soybean cropland in the Eastern Corn Belt that would be allocated to prairie strips under a program that occupies 5\% of farmers' largest fields. To do this, we first calculate the ratio of the area of the largest field to whole-farm area planted to corn or soybean (see the bottom row of Table 3). We then multiply the sample mean of the largest-field-to-total-acreage ratio by total corn-soybean planted area in the four Eastern Corn Belt states in 2017 (USDA National Agricultural Statistics Service 2017) to estimate the base area occupied by farmers' largest corn-soybean fields. We multiply the resulting base area by $5 \%$ to calculate the maximum potential land area converted to prairie strips under $100 \%$ program enrollment. To estimate the potential prairie strip acreage supplied, we multiply the maximum potential prairie strip land area by the predicted probability of contract enrollment from our logit results across the range of payment levels across the four Eastern Corn Belt states in 2017. Figure 
2 graphs the relationship between payment level and the predicted, unweighted, acreage supply, both by state and in aggregate. At the benchmark payment level of $\$ 159 /$ acre, the average annual CRP rental payment in the four states, the projected area supply is 89,500 acres of cropland converted to in-field prairie strips (ignoring land that farmers might convert voluntarily).

Figure 3 displays the range of annual incentive payment costs that we estimate the federal government would incur for a program that pays farmers to plant various acreages in prairie strips. Actual government expenditures will depend on both farmer willingness-to-accept (represented by the supply curves in Figure 2) and specific policy design. To capture the range of possible expenditures that may result from different policy decisions, we calculate projected expenditures using methods that represent two policy extremes. First, we consider a "single price" policy where all enrolled farmers receive the same payment rate, by multiplying the targeted number of acres by the bid level required to enroll the marginal acre. Such a policy would be fair but would pay many farmers a producer surplus that exceeds what they as individuals would require to adopt prairie strips. Second, we consider a policy of perfect price targeting, where each farmer receives exactly the minimum payment they are willing to accept, by computing the positive area under the aggregate supply curve. These extremes are used to benchmark the upper and lower bounds of projected payment costs. Figure 3 (and Table A21 in Supplementary Material) presents the estimated payment costs of a prairie strip conservation program on corn-soybean land in the Eastern Corn Belt at increasing acreage levels.

Note that our empirical model implies that some farmers would adopt prairie strips without payment. Across the four Eastern Corn Belt states, we predict that approximately 40,000 acres could be planted in prairie strips without incentives. Therefore, our program cost projections only consider the additional acres beyond those that we predict that farmers would provide for free. 
Per Figure 3, we estimate that the annual cost of payments to induce Eastern Corn Belt farmers to shift 100,000 acres of corn and soybean to prairie strips would range from $\$ 6$ to $\$ 18$ million. This area rounds up from the 89,500 acres that would cost $\$ 14.2$ million at a uniform payment of $\$ 159$ per acre. Such a 100,000 acre program would convert $4.4 \%$ of corn and soybean cropland in the region to a management system where prairie strips occupy 5\% of farmers' corn and soybean fields. The lower bound estimate represents the integrated area under the land supply curve, corresponding to a program that pays farmers the minimum payment they are willing to accept, while the upper bound estimate represents the cost of a program where all farmers are paid the amount required to induce participation by the farmer with the highest minimum willingness to accept.

\section{Discussion}

We find that at payment rates similar to the current Conservation Reserve Program, a fifth of the farmers surveyed are willing to plant prairie strips into corn and soybean fields. This magnitude of interest signals the potential to transform a meaningful share of cropland in the Eastern Corn Belt. Although farmers are wary of opportunity costs and direct costs, such a program is consistent with the stewardship values that many of them hold. The results dovetail well with the existing literature related to all three of our research objectives.

\section{Objective 1: Overall Willingness of Farmers to Adopt Prairie Strips}

Farmers are quite amenable to adopting prairie strips under payment scenarios similar to those used in the Conservation Reserve Program. Approximately 20\% of Eastern Corn Belt farmers would willingly enroll in a prairie strip contract if offered CRP-equivalent payments. Such a payment level would apparently offset prairie strip adoption costs— both direct and indirect opportunity costs (Tyndall 
et al. 2013). A cautious extrapolation below the minimum payment offer indicates that some farmers might adopt prairie strips without payment. Our interpretation is these farmers perceive that the expected private benefits and environmental stewardship value they would experience from prairie strips outweighs the expected costs of adoption. This finding is consistent with prior evidence that farmers with environmentally oriented attitudes are more prone to adopt conservation practices, even absent incentive payments (Pannell et al. 2006; Luther, Swinton, and Van Deynze 2020).

\section{Objective 2: Determinants of Willingness to Adopt Prairie Strips}

Incentive payment offers clearly boost the likelihood that farmers adopt prairie strips. Holding other variables at their sample means, the marginal effect of a $\$ 100$ increase in payment level is to increase by $14 \%$ the likelihood of adoption. Our results are consistent with findings elsewhere that financial compensation encourages farmer adoption of conservation practices (Bremer, Farley, and Lopez-Carr 2014; Arbuckle 2015; Yeboah, Lupi, and Kaplowitz 2015). Payments turn the conservation practice into a revenue generator that contributes to profitability, offsetting opportunity costs from taking land out of production (Cary and Wilkinson 1997; Pannell et al. 2006; Liu et al. 2018).

The finding that farmers are more willing to adopt prairie strips on smaller fields fits with reducing both monetary opportunity costs and the risk of depressing adjacent agricultural production. Past literature has documented how opportunity costs (Liu et al. 2018) and land use restrictions (Wachenheim et al. 2018) can deter adoption of conservation practices. The preference to adopt prairie strips on smaller fields is also consistent with the conceptual model assumption that farmers experience diminishing marginal utility from environmental stewardship. However, there is evidence that the environmental benefits from prairie strips increase with field area and contiguity (Schulte et al. 2016). 
Accordingly, policymakers who aim to optimize net benefits may wish to identify ways to compensate farmers at per-acre rates that increase with field size.

Perceived profitability has been shown repeatedly to drive farmer adoption of best management practices (Cary and Wilkinson 1997; Pannell et al. 2006; Liu et al. 2018). Consistent with prior studies that find expected private profitability effects to be especially compelling (Chouinard et al. 2008), the perceived yield gain factor from prairie strips has the strongest positive effect among the attitudinal factors. As a cautionary note, agronomic research has not found prairie strips to benefit yields on remaining cropland (Schulte et al. 2017). Farmer perceptions that prairie strips reduce farm management costs also encourage adoption, albeit to a smaller extent and only in the unweighted analysis (so truer on larger farms). The magnitude of the coefficient on this cost reduction factor was less than half that of the yield gain factor.

Soil retention blends environmental stewardship with agricultural productivity benefits. Farmers who perceive that prairie strips help with soil retention tend to favor prairie strip adoption. In this case, the effect size is less than a quarter the magnitude of the perceived yield gain effect in the unweighted analysis. Because prairie strips have been successfully shown to improve soil retention (Zhou, Al-Kaisi, and Helmers 2009; Helmers et al. 2012; Schulte et al. 2017), disseminating information to farmers on the extent of the private soil quality benefits from prairie strips could modestly encourage adoption (Yeboah, Lupi, and Kaplowitz 2015), particularly among farmers who experience regular or heavy soil loss.

\section{Objective 3: Potential Supply of Land for Prairie Strips}

Our results indicate that payments to Eastern Corn Belt farmers comparable to existing CRP payments could support widespread prairie strip adoption. We estimate that a program that paid farmers 
the regional average CRP land rental payment of $\$ 159 /$ acre would attract 89,500 acres of cropland into prairie strips, an area corresponding to 1.8 million acres of cropland where $5 \%$ was allocated to prairie strips.

Our program cost analysis predicts that a prairie strip program in the Eastern Corn Belt that aims to convert 100,000 corn-soybean acres to prairie strips would have payment costs in the range of \$6-18 million annually, depending on how the payment scheme is structured. In 2017 , farmers in the four Eastern Corn Belt states received \$258,372,000 in CRP rental payments to enroll 1,511,385 acres into CRP (Barbarika 2017). Our findings suggest that acreage equivalent to $6.6 \%$ of CRP-enrolled acres could be planted in prairie strips at costs ranging from 2.3\%-6.8\% of CRP expenditures across these four states in 2017 . A program that seeks to allocate 200,000 acres toward prairie strips (13.2\% of CRPenrolled acres) would do so at costs ranging from $\$ 33$ to $\$ 70$ million (12.6\%-27.1\% of CRP expenditures). The drop in program efficiency relative to CRP at higher enrollment goals results from the rising marginal cost of attracting more participants.

Our results suggest that extensive adoption of prairie strips looks entirely feasible under current federal conservation budgets, particularly when policymakers use conservation auctions to tailor payments to what individual farmers are willing to accept. Two caveats are in order. First, as PalmForster et al. (2016) have shown, actual program costs are likely to be higher than such minimum estimates, due to transaction costs and strategic behavior inherent in conservation auctions. Second, although the single binary choice used here has been shown to be incentive compatible in willingnessto-pay surveys, experimental research suggests that in a context like this one of a private good (cropland) and a new program (prairie strip payments), respondents have an incentive to exaggerate their true willingness to adopt (provision bias), in hopes that the program will be provided (Lloyd-Smith and Adamowicz 2018). We realized that "cheap talk" scripts encouraging truthful responses, follow-up 
questions on motivations and interpretation of consequentiality, and auction-based elicitation methods can alleviate incentive compatibility concerns, but we were unable to include these approaches in this study due to limited questionnaire space and concerns of survey fatigue. Both caveats suggest that the actual supply of land for prairie strips would likely be lower than the one estimated here from stated preferences.

This research opens the door for important extensions. First, as implied by our conceptual model, farmers are likely to vary in the land area that they would willingly set aside for prairie strips at any given payment rate. Empirically, this study limited the land area to 5\% of the farm's largest corn or soybean field. Future research could provide a more detailed picture of willingness to adopt prairie strips by varying the proportion of cropland allocable for prairie strips and the range of fields eligible. For example, prairie strips could have greater adoption potential where the opportunity costs from foregone crop revenue are lower. Farmers could mitigate their opportunity costs by choosing to plant prairie strips on lower quality cropland (Claassen and Tegene 1999), low-profitability sub-plots of their fields (Brandes et al. 2016), or cropland with high yield variability (Martinez-Feria and Basso, 2020).

As with CRP in general, prairie strips will have lower opportunity costs when expected future crop prices are low, so prairie strips may see greater adoption when crop prices slump. Future research repeating similar stated preference surveys over time, either through additional cross sections or a panel, should address how crop price dynamics affect prairie strip adoption behavior and how flexible contract characteristics might alleviate the impact of opportunity costs as an adoption barrier.

Finally, it is possible that enrollment in other conservation programs may affect how much land a farm has available for adopt prairie strips. Future surveys that measure conservation program participation in greater detail could test the hypothesis that such enrollments affect prairie strip supply. 
Since 2019, prairie strips have been eligible for federal payments under the CRP Clean Lakes, Estuaries and Rivers (CRP-CLEAR) initiative. Practices covered under CRP-CLEAR are intended to improve water quality both near and far from farming sites through decreased soil erosion and nutrient loadings, and through increased wildlife habitat (USDA 2019). While prairie strips are formally a setaside practice under CRP-CLEAR, they are unique in being located inside crop fields, where they act like a working lands practice that would otherwise be eligible for support under the Environmental Quality Incentives Program (EQIP) or the Conservation Stewardship Program (Kemp 2009). Nearly 10,000 acres across the U.S., including nearly 5,000 in states represented in this study, had been converted to prairie strips under the CRP-CLEAR program as of February 2021 (USDA FSA 2021). These early contracts represent a promising start for an incentive program similar in nature to the hypothetical program studied here. Our results suggest that, absent budgetary and eligibility constraints and assuming that farmers are fully informed and face negligible transaction costs to participate, the CRP-CLEAR program can expect up to an 18-fold prairie strip acreage expansion in the Illinois, Indiana, Michigan, and Ohio.

Prairie strips have primarily been researched in contexts where they are planted inside crop fields, but CRP-CLEAR also supports prairie plantings along field margins, in irrigation pivot corners, in terrace channels or next to waterways (USDA 2019). While farmers can mitigate opportunity costs by choosing to plant elsewhere than across the inside of crop fields (Brandes et al. 2016), certain ecosystem services provided by prairie strips are likely enhanced when prairie strips are spaced regularly inside crop fields (Schulte et al. 2016). Future research should explore ecosystem services when prairie patches are located where opportunity cost is low as compared with planting along topographic contours (for soil conservation) or at regular spacing (for pollination and natural pest biocontrol) within row crop fields rather than elsewhere. A valuable complement to research into ecosystem services from placing 
prairie strips where opportunity cost is low would be research to identify the spatial configuration of prairie strips that maximizes the value of ecosystem services (Meehan et al. 2013).

Future cost-benefit analyses should link farmer models of willingness-to-adopt with agroecological models of the environmental benefits from prairie strips. Such linkage would enable studying how these ecosystem services (and farmer valuations of these services compared to their expected costs) differ under alternative prairie strip management systems. This kind of research could assist in identifying the most desirable ways to target prairie strip adoption and could extend the supply curve of prairie strips presented in this paper to a supply curve for ultimate public ecosystem services that result from prairie strips.

\section{Conclusions}

Prairie strips have been shown to provide a wide array of ecosystem services both to farmers and to the public. However, absent incentive payments, the direct costs of installation and maintenance plus the opportunity cost of foregone crop income are entirely borne by farmers, forcing farmers to make a trade-off between improved environmental quality and agricultural profits.

We find that this trade-off is not a prohibitive barrier for farmers to adopt prairie strips. Farmers surveyed in the Eastern Corn Belt show considerable willingness to shift working cropland into prairie strips in exchange for payments similar to those used in current conservation initiatives. At payment levels equal to in-state CRP averages, approximately $20 \%$ of farmers would adopt prairie strips on their largest corn or soybean field. The acreage they are willing to switch into prairie strips rises with the level of payments offered and farmer perceptions of higher yields and larger environmental benefits. By contrast, available acreage falls when farmers manage larger field areas and when adoption is perceived to increase costs. 
Current farmer knowledge of prairie strips and their effects remains at a formative stage. Farmer willingness to adopt them hinges in part on perceptions of likely crop productivity and environmental effects. Those perceptions will be shaped by ongoing research that will help to inform the location- and price-specific thresholds where the additional benefits from planting prairie strips inside crop fields offset the attendant opportunity costs. Of particular value will be research that expands our knowledge 1) ecologically, beyond soil and water conservation to measure biodiversity benefits, 2) economically, to discern the appeal of prairie plantings at low-earning sites in farm fields, and 3) ecologically and economically, to determine the benefits and costs of siting in-field prairie plantings where opportunity costs are low.

\section{Acknowledgements}

The authors were all based at Michigan State University at the time of the research. They acknowledge financial support for this research from the NSF Long-term Ecological Research Program (DEB 1832042) at the Kellogg Biological Station, Michigan State University AgBioResearch, and the USDA National Institute of Food and Agriculture. They thank Sandra Marquart-Pyatt, Riva Denny, and Matthew Houser for assistance with survey design and implementation; Nicholas Haddad, David Hennessy, Douglas Landis, and Frank Lupi for helpful comments; and especially the respondents to the 2018 Crop Management and Stewardship Practices survey.

\section{References}


Arbuckle, J. Gordon Jr. 2015. "Investigating Opportunities for Enhancing Adoption of Strategically Targeted Prairie Strips in Iowa." Sociology Technical Reports 9. Available at https://dr.lib.iastate.edu/entities/publication/327468da-9910-4a94-bebb-3cf48432ef4f.

Barbarika, Alex. 2017. "Conservation Reserve Program Monthly Summary-September 2017." Farm Service Agency, USDA, Washington, DC. Available at https://www.fsa.usda.gov/Assets/USDAFSA-Public/usdafiles/Conservation/PDF/September2017Summary.pdf.

Baumgart-Getz, Adam, Linda Stalker Prokopy, and Kristin Floress. 2001. "Why Farmers Adopt Best Management Practice in the United States: A Meta-Analysis of the Adoption Literature." Journal of Environmental Management 96 (1): 17-25.

Bouchard, Natalie R., Deanna L. Osmond, Ryan J. Winston, and William F. Hunt. 2013. "The Capacity of Roadside Vegetated Filter Strips and Swales to Sequester Carbon." Ecological Engineering 54: $227-232$.

Brandes, Elke, Gabriel Sean McNunn, Lisa A. Schulte, Ian J. Bonner, D. J. Muth, Bruce A. Babcock, Bhavna Sharma, and Emily A. Heaton. 2016. "Subfield Profitability Analysis Reveals an Economic Case for Cropland Diversification." Environmental Research Letters 11 (1): 014009. https://doi.org/10.1088/1748-9326/11/1/014009.

Bremer, Leah L., Kathleen A. Farley, and David Lopez-Carr. 2014. "What Factors Influence Participation in Payment for Ecosystem Services Programs? An Evaluation of Ecuador's SocioPáramo Program." Land Use Policy 36: 122-133.

Claassen, Roger, and Abebayehu Tegene. 1997. "Agricultural Land Use Choice: A Discrete Choice Approach." Agricultural and Resource Economics Review 28 (1): 26-36.

Cary, John W., and Roger L. Wilkinson. 1997. "Perceived Profitability and Farmers' Conservation Behaviour." Journal of Agricultural Economics 48 (1-3): 13-21. 
Chouinard, Hayley H., Tobias Paterson, Philip R. Wandschneider, and Adrienne M. Ohler. 2008. "Will Farmers Trade Profits for Stewardship? Heterogeneous Motivations for Farm Practice Selection." Land Economics 84 (1): 66-82.

Cox, Rachael, Matthew O'Neal, Rene Hessel, Lisa A. Schulte, and Matthew Helmers. 2014. "The Impact of Prairie Strips on Aphidophagous Predator Abundance and Soybean Aphid Predation in Agricultural Catchments." Environmental Entomology 43 (5): 1185-1197.

Daloğlu, Irem, Joan Iverson Nassauer, Rick L. Riolo, and Donald Scavia. 2014. "Development of a Farmer Typology of Agricultural Conservation Behavior in the American Corn Belt." Agricultural Systems 129: 93-102.

Duffield, John W., and David A. Patterson. 1991. "Inference and Optimal Design for a Welfare Measure in Dichotomous Choice Contingent Valuation." Land Economics 67 (2): 225-239.

Dupraz, Pierre, Dominique Vermersch, B. Henry De Frahan, and Lionel Delvaux. 2003. "The Environmental Supply of Farm Households: A Flexible Willingness to Accept Model." Environmental and Resource Economics 25 (2): 171-189.

Gill, Kelly Ann, R. Cox, and Matthew E. O'Neal. 2014. "Quality over Quantity: Buffer Strips Can Be Improved with Select Native Plant Species." Environmental Entomology 43 (2): 298-311.

Guto, S. N., Pieter Pypers, Bernard Vanlauwe, N. de Ridder, and Ken E. Giller. 2011. "Tillage and Vegetative Barrier Effects on Soil Conservation and Short-Term Economic Benefits in the Central Kenya Highlands." Field Crops Research 122 (2): 85-94.

Haaland, Christine, Russell E. Naisbit, and Louis-Félix Bersier. 2011. "Sown Wildflower Strips for Insect Conservation: A Review." Insect Conservation and Diversity 4 (1): 60-80. 
Helmers, Matthew J., Thomas M. Isenhart, Michael G. Dosskey, Seth M. Dabney, and Jeffrey S. Strock. 2008. "Buffers and Vegetative Filter Strips." Agricultural and Biosystems Engineering Publications 298. Available at https://lib.dr.iastate.edu/abe_eng_pubs/298.

Helmers, Matthew J., Xiaobo Zhou, Heidi Asbjornsen, Randy Kolka, Mark D. Tomer, and Richard M. Cruse. 2012. "Sediment Removal by Prairie Filter Strips in Row-Cropped Ephemeral Watersheds." Journal of Environmental Quality 41 (5): 1531-1539.

Hirsh, Sarah M., Catherine M. Mabry, Lisa A. Schulte, and Matt Liebman. 2013. "Diversifying Agricultural Catchments by Incorporating Tallgrass Prairie Buffer Strips." Ecological Restoration 31 (2): 201-211.

Hernandez-Santana, V., X. Zhou, Matthew J. Helmers, Heidi Asbjornsen, Randy Kolka, and M. Tomer. 2013. "Native Prairie Filter Strips Reduce Runoff from Hillslopes Under Annual Row-Crop Systems in Iowa, USA." Journal of Hydrology 477: 94-103.

Kemp, Loni. 2009. "The Farmers' Guide to the Conservation Stewardship Program." National Sustainable Agriculture Coalition. Available at http://sustainableagriculture.net/wpcontent/uploads/2011/09/NSAC-Farmers-Guide-to-CSP-2011.pdf

Lane, Ian G., Christina R. Herron-Sweet, Zachary M. Portman, and Daniel P. Cariveau. 2020. "Floral Resource Diversity Drives Bee Community Diversity in Prairie Restorations Along an Agricultural Landscape Gradient." Journal of Applied Ecology 2020;00: 1-9. https://doi.org/10.1111/1365$\underline{2664.13694}$

Liu, Tingting, Randall JF Bruins, and Matthew T. Heberling. 2018. "Factors Influencing Farmers' Adoption of Best Management Practices: A Review and Synthesis." Sustainability 10 (2): 432. 
Lloyd-Smith, Patrick and Wiktor Adamowicz. 2018. "Can Stated Measures of Willingness-To-Accept Be Valid? Evidence From Laboratory Experiments.” Journal of Environmental Economics and Management 91:133-149.

Love, Fred. 2017. “Leaving 'Prairie Strips' On Farmland Pays Off.” Futurity. October 13, 2017. https://www.futurity.org/prairie-strips-1574002-2/.

Luther, Zachary R., Scott M. Swinton and Braeden Van Deynze. 2020. "What Drives Voluntary Adoption of Farming Practices That Can Abate Nutrient Pollution?" Journal of Soil and Water Conservation 75(5): 640-650.

Ma, Shan, Scott M. Swinton, Frank Lupi, and Christina B. Jolejole-Foreman. 2012. 'Farmers' Willingness to Participate in Payment-For-Environmental-Services Programmes.” Journal of Agricultural Economics 63(3): 604-626.

MacDonald, James M. 2020. "Tracking the Consolidation of U.S. Agriculture." Applied Economic Perspectives and Policy 42(3): 361-379.

Martinez-Feria, R.A., and B. Basso. 2020. "Unstable Crop Yields Reveal Opportunities for Site-Specific Adaptations to Climate Variability." Scientific Reports 10:2885.

Meehan, T. D., Gratton, C., Diehl, E., Hunt, N. D., Mooney, D. F., Ventura, S. J., Barham, B. L., \& Jackson, R. D. 2013. "Ecosystem-Service Tradeoffs Associated with Switching from Annual to Perennial Energy Crops in Riparian Zones of The US Midwest.” PLOS One 8(11), e80093. https://doi.org/10.1371/journal.pone.0080093.

Mooney, Daniel F., Bradford L. Barham, and Chang Lian. 2015. "Inelastic and Fragmented Farm Supply Response for Second-Generation Bioenergy Feedstocks: Ex Ante Survey Evidence from Wisconsin.” Applied Economic Perspectives and Policy 37(2): 287-310. 
Palm-Forster, Leah H., Scott M. Swinton, Frank Lupi, and Robert Shupp. 2016. "Too Burdensome to Bid: Transaction Costs and Pay-for-Performance Conservation.” American Journal of Agricultural Economics 98(5): 1314-1333.

Pannell, David J., Graham R. Marshall, Neil Barr, Allan Curtis, Frank Vanclay, and Roger Wilkinson. 2006. "Understanding and Promoting Adoption of Conservation Practices by Rural Landholders." Australian Journal of Experimental Agriculture 46 (11): 1407-1424.

Phaneuf, Daniel J., and Till Requate. 2016. A Course in Environmental Economics: Theory, Policy, and Practice. Cambridge, UK: Cambridge University Press.

Prokopy, Linda S., Kristin Floress, Denise Klotthor-Weinkauf, and Adam Baumgart-Getz. 2008. "Determinants of Agricultural Best Management Practice Adoption: Evidence from The Literature." Journal of Soil and Water Conservation 63 (5): 300-311.

Prokopy, Linda S., Kristin Floress, J. Gordon Arbuckle, Sarah P. Church, F. R. Eanes, Yuling Gao, Benjamin M. Gramig, Pranay Ranjan, and Ajay S. Singh. 2019. "Adoption of Agricultural Conservation Practices in The United States: Evidence From 35 Years of Quantitative Literature." Journal of Soil and Water Conservation 74 (5): 520-534.

Schulte, Lisa A., Anna L. MacDonald, Jarad B. Niemi, and Matthew J. Helmers. 2016. "Prairie Strips as a Mechanism to Promote Land Sharing By Birds in Industrial Agricultural Landscapes." Agriculture, Ecosystems \& Environment 220: 55-63.

Schulte, Lisa A., Jarad Niemi, Matthew J. Helmers, Matt Liebman, J. Gordon Arbuckle, David E. James, Randall K. Kolka, Matthew E. O’Neal, Mark D. Tomer, John C. Tyndall, Heidi Asbjornsen, Pauline Drobney, Jeri Neal, Gary Van Ryswyk, and Chris Witte. 2017. "Prairie Strips Improve Biodiversity and the Delivery of Multiple Ecosystem Services from Corn-Soybean Croplands." Proceedings of the National Academy of Sciences 114 (42): 11247-11252. 
Schulte Moore, Lisa, Tim Youngquist, and Matt Helmers. 2017. "A Landowner's Guide to Prairie Strips." Extension and Outreach Publications. 578. Available at https://lib.dr.iastate.edu/extension_pubs/578.

Skevas, Theodoros, Noel J. Hayden, Scott M. Swinton, and Frank Lupi. 2016. "Landowner Willingness to Supply Marginal Land for Bioenergy Production.” Land Use Policy, 50, 507-517.

Solon, Gary, Steven J. Haider, and Jeffrey M. Wooldridge. 2015. "What Are We Weighting For?" Journal of Human Resources 50 (2): 301-316.

Swinton, Scott M., Natalie Rector, G. Philip Robertson, Christina B. Jolejole-Foreman, and Frank Lupi. 2015. "Farmer Decisions about Adopting Environmentally Beneficial Practices.” In The Ecology of Agricultural Landscapes: Long-term Research on the Path to Sustainability, ed. Stephen K. Hamilton, Julie E. Doll, and G.Philip Robertson, 340-359. New York: Oxford University Press. Thompson, Bruce. 2004. Exploratory and Confirmatory Factor Analysis: Understanding Concepts and Applications. Washington, DC: American Psychological Association.

Tyndall, John C., Lisa A. Schulte, Matthew Liebman, and Matthew Helmers. 2013. "Field-Level Financial Assessment of Contour Prairie Strips for Enhancement of Environmental Quality." Environmental Management, 52(3), 736-747.

U.S. Congress. 2018. “Agriculture Improvement Act of 2018.” In 115th Congress. Public Law 334. U.S. Government Publishing Office, Washington D.C. Available at https://www.govinfo.gov/content/pkg/PLAW-115publ334/pdf/PLAW-115publ334.pdf.

U.S. Department of Agriculture (USDA) Farm Service Agency. 2019. “Conservation Reserve Program:

Clean Lakes, Estuaries and Rivers (CLEAR) Initiative: Prairie Strip Practice (CP-43).” Available at https://www.fsa.usda.gov/Assets/USDA-FSA-

Public/usdafiles/FactSheets/2019/crp_clear_initiative_prairie_strip_practice-fact_sheet.pdf. 
USDA Farm Service Agency. 2021. “Conservation Reserve Program Monthly Summary - February 2021." Available at https://www.fsa.usda.gov/Assets/USDA-FSA-

Public/usdafiles/Conservation/PDF/Summary\%20February\%202021\%20CRPMonthly.pdf.

USDA National Agricultural Statistics Service. 2017. “2017 Acreage Data as Of January 16, 2018.” NASS - Quick Stats. USDA National Agricultural Statistics Service. Available at https://www.fsa.usda.gov/news-room/efoia/electronic-reading-room/frequently-requestedinformation/crop-acreage-data/index.

USDA National Agricultural Statistics Service. 2021. "Corn and Soybean Acres Planted in the U.S. Corn Belt, 1924-2021.” NASS - Quick Stats. USDA National Agricultural Statistics Service. Available at https://quickstats.nass.usda.gov/results/C69DFC5F-AB71-35DF-B223EC20DDA7996A.

Wachenheim, C., D. C. Roberts, N. Dhingra, N, W. Lesch, and J. Devney. 2018. “Conservation Reserve Program Enrollment Decisions in the Prairie Pothole Region.” Journal of Soil and Water Conservation 73 (3): 337-352.

Werling, Ben P., Timothy L. Dickson, Rufus Isaacs, Hannah Gaines, Claudio Gratton, Katherine L. Gross, Heidi Liere, Carolyn M. Malmstrom, Timothy D. Meehan, Leilei Ruan, L., Bruce A. Robertson, G. Philip Robertson, Thomas M. Schmidt, Abbie C. Schrotenboer, Tracy K. Teal, Julianna K. Wilson, and Douglas A. Landis. 2014. "Perennial Grasslands Enhance Biodiversity and Multiple Ecosystem Services in Bioenergy Landscapes.” Proceedings of the National Academy of Sciences 111 (4): 1652-1657.

Yeboah, Fellix Kwame, Frank Lupi, and Michael D. Kaplowitz. 2015. "Agricultural Landowners' Willingness to Participate in A Filter Strip Program for Watershed Protection." Land Use Policy 49:75-85. 
Zhou, X., Al-Kaisi, M., and M.J. Helmers. 2009. "Cost Effectiveness of Conservation Practices in Controlling Water Erosion in Iowa." Soil and Tillage Research 106 (1): 71-78. 


\section{Tables}

\section{Table 1}

Payment offer treatments (USD/Acre/Year) by state. $\mathrm{N}=487$.

\begin{tabular}{cccccc}
\hline $\begin{array}{c}\text { Treatment } \\
\text { (\% of state-wide } \\
\begin{array}{c}\text { avg. CRP rate, } \\
\text { Sept. 2017) }\end{array}\end{array}$ & $\begin{array}{c}\text { Illinois } \\
\text { (\# of Obs.) }\end{array}$ & $\begin{array}{c}\text { Indiana } \\
\text { (\# of Obs.) }\end{array}$ & $\begin{array}{c}\text { Michigan } \\
\text { (\# of Obs.) }\end{array}$ & $\begin{array}{c}\text { Ohio } \\
\text { (\# of Obs.) }\end{array}$ & $\begin{array}{c}\text { Three-State } \\
\text { Average of IL, } \\
\text { IN, OH) } \\
\text { (\# of Obs. })\end{array}$ \\
\hline $50 \%$ & $\$ 90$ & $\$ 84$ & $\$ 64$ & $\$ 80$ & $\$ 87$ \\
$100 \%$ & $(30)$ & $(22)$ & $(25)$ & $(20)$ & $(22)$ \\
& $\$ 180$ & $\$ 167$ & $\$ 127$ & $\$ 161$ & $\$ 175$ \\
$200 \%$ & $(33)$ & $(22)$ & $(21)$ & $(32)$ & $(19)$ \\
$300 \%$ & $\$ 360$ & $\$ 334$ & $\$ 254$ & $\$ 322$ & $\$ 350$ \\
& $(33)$ & $(16)$ & $(18)$ & $(31)$ & $(23)$ \\
& $\$ 540$ & $\$ 501$ & $\$ 381$ & $\$ 483$ & $\$ 525$ \\
Total \# of Obs. & $(29)$ & $(28)$ & $(13)$ & $(30)$ & $(20)$ \\
\hline
\end{tabular}




\section{Table 2}

Factor loadings from confirmatory factor analysis for 6 latent perception variables.

\begin{tabular}{|c|c|c|c|}
\hline $\begin{array}{l}\text { Perceived } \\
\text { Outcomes }\end{array}$ & & Value Statement & Factor Loading \\
\hline \multirow{3}{*}{ 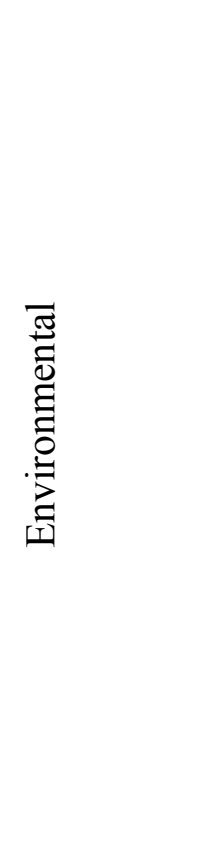 } & 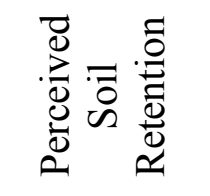 & $\begin{array}{l}\text { Soil erosion } \\
\text { Nutrient runoff }\end{array}$ & $\begin{array}{l}1.00 \\
1.12\end{array}$ \\
\hline & 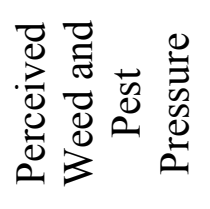 & $\begin{array}{l}\text { Weed populations } \\
\text { Insect populations }\end{array}$ & $\begin{array}{l}1.00 \\
0.75\end{array}$ \\
\hline & 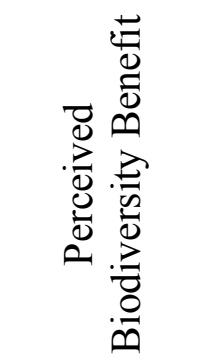 & $\begin{array}{l}\text { Populations of natural enemies of pests } \\
\text { Pollinator populations } \\
\text { Wildflower populations }\end{array}$ & $\begin{array}{l}1.00 \\
1.66 \\
1.42\end{array}$ \\
\hline \multirow{7}{*}{ 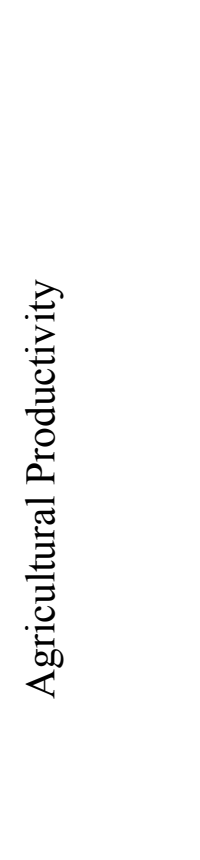 } & 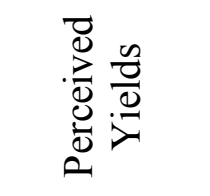 & $\begin{array}{l}\text { Crop yields per cropped acre } \\
\text { Crop yields for entire field }\end{array}$ & $\begin{array}{l}1.00 \\
1.64\end{array}$ \\
\hline & 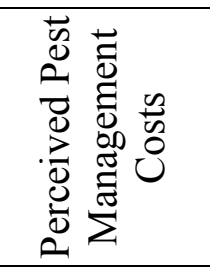 & $\begin{array}{l}\text { Weed control costs per cropped acre } \\
\text { Pest control costs per cropped acre }\end{array}$ & $\begin{array}{l}1.00 \\
0.77\end{array}$ \\
\hline & $=\frac{\infty}{0}$ & Tillage costs per cropped acre & 1.00 \\
\hline & 芫 & Planting costs per cropped acre & 1.28 \\
\hline & D & Total costs for entire field & 1.16 \\
\hline & 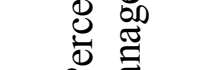 & Time spent working field & 1.09 \\
\hline & $\sum$ & Harvest costs per cropped acre & 1.12 \\
\hline
\end{tabular}


Table 3

Descriptive statistics for key variables

\begin{tabular}{|c|c|c|c|c|c|c|c|}
\hline $\begin{array}{c}\text { Conceptual } \\
\text { Model } \\
\text { Component }\end{array}$ & $\begin{array}{c}\text { Empirical } \\
\text { Variable }\end{array}$ & Units & Mean & SD & Min & Max & $\begin{array}{l}\text { Hypothesized } \\
\text { Impact on } \\
\text { Adoption }\end{array}$ \\
\hline - & $\begin{array}{l}\text { Contract } \\
\text { Enrollment }{ }^{1}\end{array}$ & $(0 / 1)$ & 0.38 & 0.49 & 0 & 1 & N.A. \\
\hline$R$ & $\begin{array}{l}\text { Payment } \\
\text { Offer }\end{array}$ & USD/Acre/Year & 266.7 & 161.8 & 64 & 540 & $(+)$ \\
\hline$\alpha^{*} A$ & Prairie Strip Land & Acres & 5.11 & 3.87 & 0.5 & 30.3 & $(-)$ \\
\hline$E$ & $\begin{array}{l}\text { Perceived Yield } \\
\text { Gains }\end{array}$ & - & 0.00 & 0.26 & -0.93 & 1.02 & $(+)$ \\
\hline$E$ & $\begin{array}{c}\text { Perceived Pest } \\
\text { Management Costs }\end{array}$ & - & 0.00 & 0.48 & -1.95 & 1.66 & $(-)$ \\
\hline$E$ & $\begin{array}{l}\text { Perceived Farm } \\
\text { Management Costs }\end{array}$ & - & 0.00 & 0.42 & -1.68 & 1.51 & $(-)$ \\
\hline E & $\begin{array}{l}\text { Perceived Soil } \\
\text { Retention }\end{array}$ & - & 0.00 & 0.62 & -2.37 & 1.16 & $(+)$ \\
\hline$E$ & $\begin{array}{l}\text { Perceived Weed and } \\
\text { Pest Pressure }\end{array}$ & - & 0.00 & 0.57 & -2.14 & 1.47 & $(-)$ \\
\hline$E$ & $\begin{array}{c}\text { Perceived } \\
\text { Biodiversity Benefit }\end{array}$ & - & 0.00 & 0.35 & -1.51 & 0.76 & $(+)$ \\
\hline$E$ & $\begin{array}{c}\text { Conservation } \\
\text { Program Participant }\end{array}$ & $0 / 1$ & 0.37 & 0.48 & 0 & 1 & $(+)$ \\
\hline
\end{tabular}

All variables are explanatory variables unless otherwise noted.

Signs of expected effects: $(+)$ denotes positive, $(-)$ denotes negative. N.A. denotes not applicable (i.e., no expected effect).

${ }^{1}$ All variables are explanatory variables, except for Contract Enrollment, which is a dependent variable.

${ }^{2}$ Land-share variable used for acreage supply projections. $\mathrm{N}=442$ for this variable only. 


\section{Table 3 (Continued)}

Descriptive statistics for key explanatory variables

\begin{tabular}{|c|c|c|c|c|c|c|c|}
\hline $\begin{array}{c}\text { Conceptual } \\
\text { Model } \\
\text { Component }\end{array}$ & $\begin{array}{c}\text { Empirical } \\
\text { Variable }\end{array}$ & Units & Mean & SD & Min & Max & $\begin{array}{l}\text { Hypothesized } \\
\text { Impact on } \\
\text { Adoption }\end{array}$ \\
\hline$F$ & Age & Years & 61.2 & 12.0 & 20 & 101 & $(-)$ \\
\hline$F$ & Education & Categorical & 2.82 & 0.86 & $\begin{array}{c}1 \\
(<\text { High } \\
\text { School) }\end{array}$ & $\begin{array}{c}4 \\
\text { (Bachelor's } \\
\text { or Higher) }\end{array}$ & $(+)$ \\
\hline$N F I$ & Non-Farm Work & Categorical & 2.14 & 1.59 & $\begin{array}{c}1 \\
\text { (No days) }\end{array}$ & $\begin{array}{c}5 \\
\text { (200+ days) }\end{array}$ & N.A. \\
\hline$F$ & Previous PS Contact & $0 / 1$ & 0.43 & 0.49 & 0 & 1 & $(+)$ \\
\hline$\alpha^{*} A / A^{\prime}$ & $\begin{array}{l}\text { Ratio: Largest Field } \\
\text { Acreage to Planted } \\
\text { Acreage in } \\
\text { Corn/Soybean } \\
\text { Across Farm }{ }^{2}\end{array}$ & Proportion & 0.20 & 0.16 & 0.01 & 1 & N.A. \\
\hline
\end{tabular}

All variables are explanatory variables unless otherwise noted. $(\mathrm{N}=487)$.

Signs of expected effects: $(+)$ denotes positive, $(-)$ denotes negative. N.A. denotes not applicable (i.e., no expected effect).

${ }^{1}$ All variables are explanatory variables, except for Contract Enrollment, which is a dependent variable.

${ }^{2}$ Land-share variable used for acreage supply projections. $\mathrm{N}=442$ for this variable only. 
Table 4

Logit regression results for respondents' acceptance of prairie strip contracts

\begin{tabular}{|c|c|c|}
\hline $\begin{array}{l}\text { VARIABLES } \\
\text { (units) }\end{array}$ & $\begin{array}{l}\text { Unweighted } \\
\text { Logit }\end{array}$ & $\begin{array}{l}\text { Weighted } \\
\text { Logit }\end{array}$ \\
\hline $\begin{array}{l}\text { Payment Offer } \\
\text { (USD/Acre/Year) }\end{array}$ & $\begin{array}{l}0.00611^{* * *} \\
(0.000747)\end{array}$ & $\begin{array}{l}0.00735^{* * *} \\
(0.00109)\end{array}$ \\
\hline $\begin{array}{l}\text { Prairie Strip Land } \\
\text { (Acres) }\end{array}$ & $\begin{array}{l}-0.122^{* * *} \\
(0.0395)\end{array}$ & $\begin{array}{l}-0.146^{* *} \\
(0.0600)\end{array}$ \\
\hline $\begin{array}{l}\text { Perceived Yield Gains } \\
\text { (Latent) }\end{array}$ & $\begin{array}{c}2.307^{* * *} \\
(0.516)\end{array}$ & $\begin{array}{l}1.534^{*} \\
(0.800)\end{array}$ \\
\hline $\begin{array}{l}\text { Perceived Pest Manage- } \\
\text { ment Costs Latent) }\end{array}$ & $\begin{array}{c}0.540 \\
(0.391)\end{array}$ & $\begin{array}{c}0.406 \\
(0.645)\end{array}$ \\
\hline $\begin{array}{l}\text { Perceived Farm Manage- } \\
\text { ment Costs Latent) }\end{array}$ & $\begin{array}{c}-1.120^{* * *} \\
(0.434)\end{array}$ & $\begin{array}{l}-1.149 \\
(0.762)\end{array}$ \\
\hline $\begin{array}{l}\text { Perceived Soil Retention } \\
\text { (Latent) }\end{array}$ & $\begin{array}{c}0.799 * * * \\
(0.209)\end{array}$ & $\begin{array}{c}1.038^{* * *} \\
(0.329)\end{array}$ \\
\hline $\begin{array}{l}\text { Perceived Weed and } \\
\text { Pest Pressure (Latent) }\end{array}$ & $\begin{array}{l}-0.0967 \\
(0.271)\end{array}$ & $\begin{array}{l}-0.0761 \\
(0.363)\end{array}$ \\
\hline $\begin{array}{l}\text { Perceived Biodiversity } \\
\text { Benefit (Latent) }\end{array}$ & $\begin{array}{c}0.423 \\
(0.373)\end{array}$ & $\begin{array}{c}0.738 \\
(0.597)\end{array}$ \\
\hline $\begin{array}{l}\text { Age } \\
\text { (Years) }\end{array}$ & $\begin{array}{l}-0.00122 \\
(0.0100)\end{array}$ & $\begin{array}{l}-0.00539 \\
(0.0181)\end{array}$ \\
\hline $\begin{array}{l}\text { Education } \\
\text { (Categorical) }\end{array}$ & $\begin{array}{c}0.00472 \\
(0.140)\end{array}$ & $\begin{array}{l}-0.157 \\
(0.238)\end{array}$ \\
\hline $\begin{array}{l}\text { Non-Farm Work } \\
\text { (Categorical) }\end{array}$ & $\begin{array}{l}-0.0150 \\
(0.0760)\end{array}$ & $\begin{array}{l}0.0259 \\
(0.127)\end{array}$ \\
\hline $\begin{array}{l}\text { Previous Contact } \\
(0 / 1)\end{array}$ & $\begin{array}{c}0.254 \\
(0.234)\end{array}$ & $\begin{array}{c}0.569 \\
(0.356)\end{array}$ \\
\hline CRP or EQIP/CSP & $0.511^{* *}$ & 0.613 \\
\hline Participation $(0 / 1)$ & $(0.242)$ & $(0.419)$ \\
\hline Constant & $\begin{array}{c}-1.916^{* *} \\
(0.843)\end{array}$ & $\begin{array}{l}-1.618 \\
(1.409)\end{array}$ \\
\hline
\end{tabular}

Pseudo R-squared

$0.249 \quad 0.311$

$* \mathrm{p}<0.1, * * \mathrm{p}<0.05, * * * \mathrm{p}<0.01$. Standard errors in parentheses. $(\mathrm{N}=487)$. Probit results in Appendix. 


\section{Figure Titles}

\section{Figure 1}

Predicted probability of contract enrollment by a representative Eastern Corn Belt farmer, by payment offer, unweighted and weighted estimates.

\section{Figure 2}

Corn and soybean acres supplied for prairie strips by payment offer, by state and in aggregate for Illinois, Indiana, Michigan, and Ohio (unweighted).

\section{Figure 3}

Projected annual payment costs of a prairie strip incentive program at uniform and targeted payments (unweighted), by acreage supplied, four Eastern Corn Belt states. 


\section{Endnotes}

${ }^{1}$ Comparison of the 2017 U.S. Agricultural Census Oilseed and Grain Farms (NAICC category 1111) for the four states surveyed reveals that due to intentional oversampling of larger farms, the mean percentages of corn/soybean farms under 500 acres were 5-20\% smaller in the CMSP final analysis sample than in the agricultural census (Table A1 in Supplemental Materials Appendix). Linked to oversampling large farms, the percentage of respondents with off-farm work was $20 \%$ lower for the CMSP final analysis sample. Values of other key variables were within 5-10\% of census values for operator age, corn and soybean yields, and participation in conservation programs (except Ohio, where conservation program participation was 30\% higher in CMSP). We see no evidence of item nonresponse bias when comparing the CMSP response sample values to the CMSP analysis sample values.

${ }^{2}$ Results from exploratory factor analyses are available in the supplemental material Appendix, Tables A3 and A4, and are similar to those from the confirmatory analysis.

${ }^{3}$ Probability weights are available in the supplemental material Appendix, Table A5.

${ }^{4}$ Probit counterparts to all logit-based tables and figures can be found in Table A20 of the supplemental material Appendix. Probit results are very similar to the logit results. 


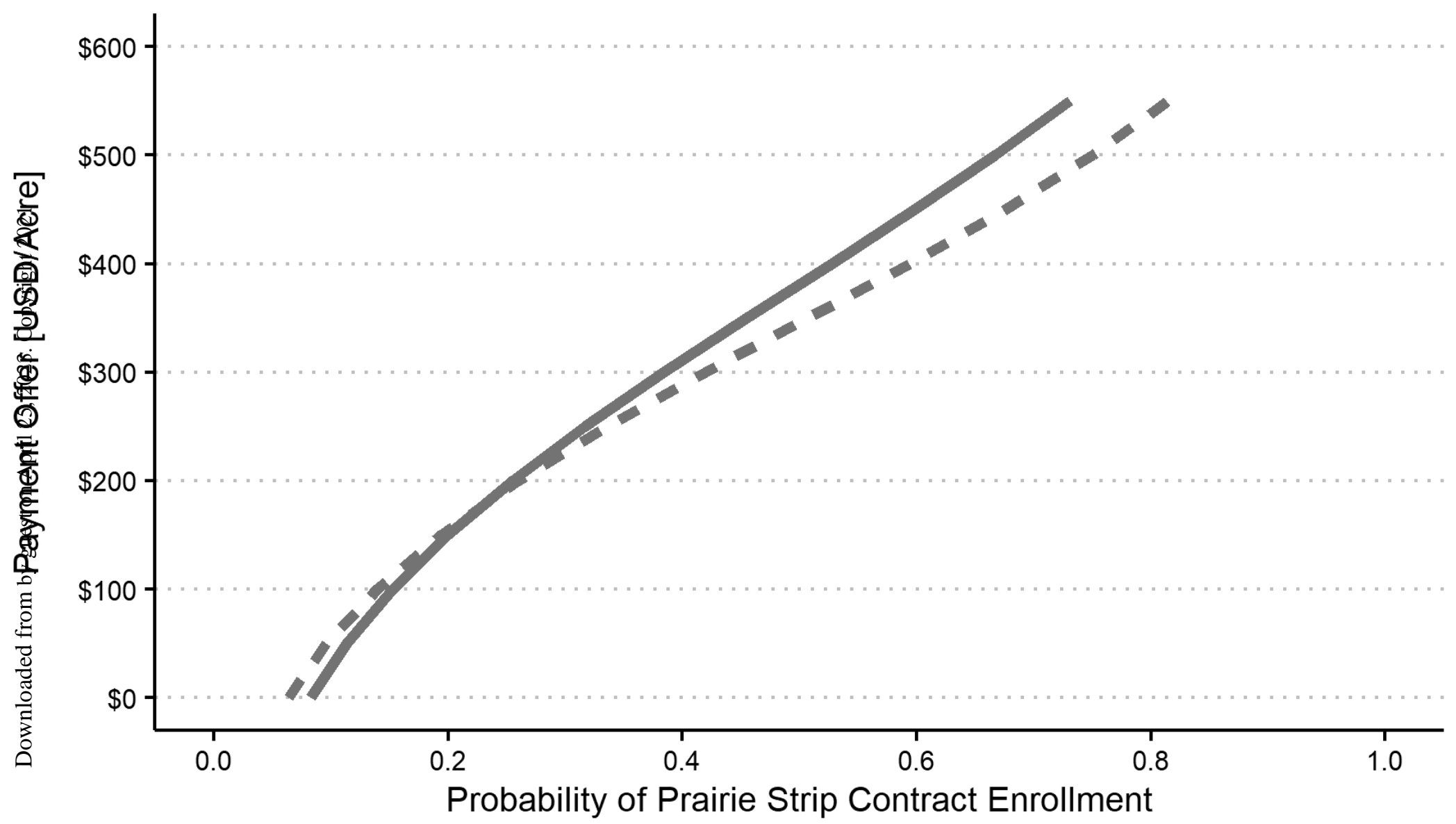

Weights Unweighted - " Weighted 


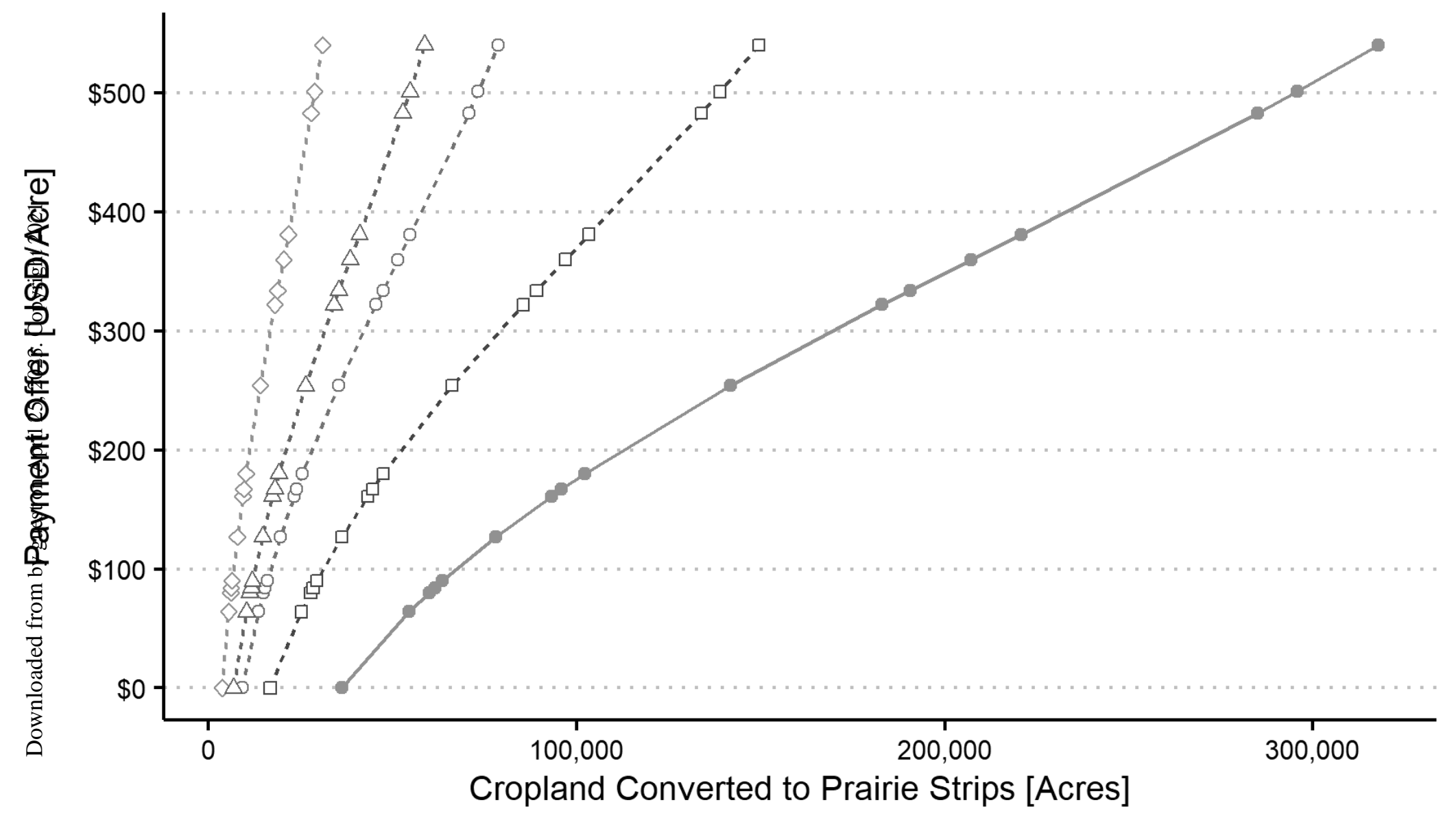

$\neg-$ Illinois $\multimap$ Indiana $\triangleleft$ Michigan $\triangleleft-$ Ohio $\rightarrow$ Total 


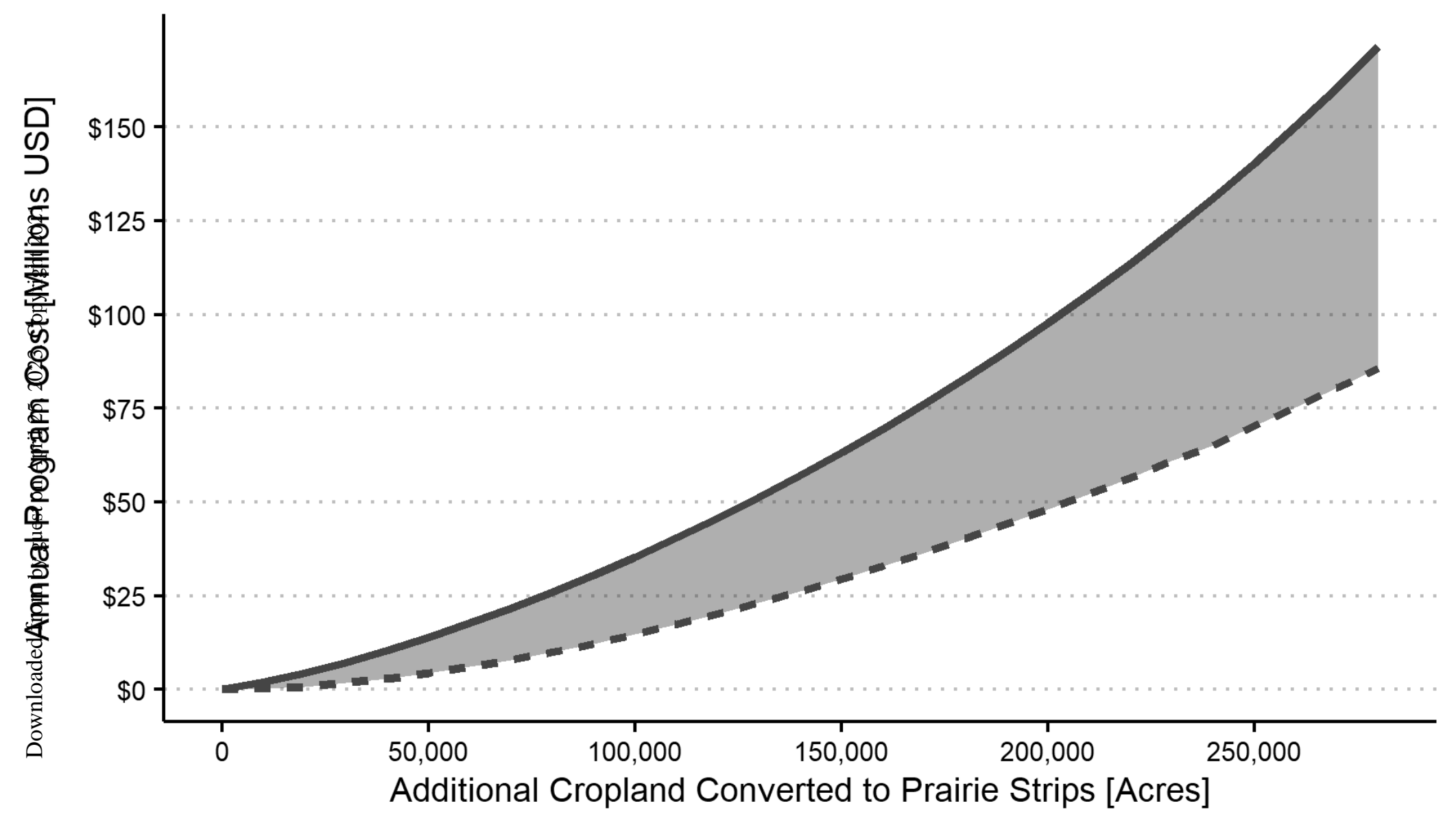

- Single Rate Program - - Targeted Rate Program 